University of Nebraska - Lincoln

DigitalCommons@University of Nebraska - Lincoln

\title{
Mutations in hns reduce the adherence of Shiga toxin-producing E. coli 091:H21 strain B2F1 to human colonic epithelial cells and increase the production of hemolysin
}

\author{
Maria E. Scott \\ American Red Cross, Rockville, MD \\ Angela R. Melton-Celsa \\ Uniformed Services University of the Health Sciences, angela.melton-celsa@usuhs.edu \\ Alison D. O'Brien \\ Uniformed Services University of the Health Sciences, alison.obrien@usuhs.edu
}

Follow this and additional works at: https://digitalcommons.unl.edu/usuhs

Part of the Medicine and Health Sciences Commons

Scott, Maria E.; Melton-Celsa, Angela R.; and O'Brien, Alison D., "Mutations in hns reduce the adherence of Shiga toxin-producing E. coli 091:H21 strain B2F1 to human colonic epithelial cells and increase the production of hemolysin" (2003). Uniformed Services University of the Health Sciences. 14.

https://digitalcommons.unl.edu/usuhs/14

This Article is brought to you for free and open access by the U.S. Department of Defense at DigitalCommons@University of Nebraska - Lincoln. It has been accepted for inclusion in Uniformed Services University of the Health Sciences by an authorized administrator of DigitalCommons@University of Nebraska Lincoln. 


\title{
Mutations in hns reduce the adherence of Shiga toxin-producing E. coli 091:H21 strain B2F1 to human colonic epithelial cells and increase the production of hemolysin
}

\author{
Maria E. Scott ${ }^{\mathrm{a}}$, Angela R. Melton-Celsa ${ }^{\mathrm{b}}$, Alison D. O'Brien ${ }^{\mathrm{b}, *}$ \\ ${ }^{\mathrm{a}}$ Department of Biochemistry, American Red Cross, Rockville, MD 20855, USA \\ ${ }^{\mathrm{b}}$ Department of Microbiology and Immunology, F. Edward Hébert School of Medicine, Uniformed Services University of the Health Sciences, \\ 4301 Jones Bridge Road, Bethesda, MD 20814-4799, USA
}

Received 10 October 2002; received in revised form 9 December 2002; accepted 9 December 2002

\begin{abstract}
Shiga toxin-producing Escherichia coli (STEC) 091:H21 strain B2F1, an isolate from a patient with the hemolytic uremic syndrome (HUS), produces elastase-activatable Shiga toxin (Stx) type $2 \mathrm{~d}$ and adheres well to human colonic epithelial T84 cells. This adherence phenotype occurs even though B2F1 does not contain the locus of enterocyte effacement (LEE) that encodes the primary adhesin for $E$. coli O157:H7. To attempt to identify genes involved in binding of B2F1 to T84 cells a bank of mini-Tn5phoACm ${ }^{\mathrm{r}}$ transposon mutants of this strain was generated. Several of these mutants exhibited a reduced adherence phenotype, but none of the insertions in these mutants were within putative adhesin genes. Rather, insertional mutations within hns resulted in the loss of adherence. Moreover, the hns mutant also displayed an increase in the production of hemolysin and alkaline phosphatase and a loss of motility with no change in Stx2d-activatable expression levels. When B2F1 was cured of the large plasmid that encodes the hemolysin, the resulting strain adhered well to T84 cells. However, an hns mutant of the plasmid-cured B2F1 strain exhibited a reduction in adherence to T84 cells. Taken together, these results indicate that H-NS regulates the expression of several genes and some potential virulence factors in the intimin-negative B2F1 STEC strain and that the large plasmid is not required for T84 cell colonization.

Published by Elsevier Science Ltd.
\end{abstract}

Keywords: B2F1; Adherence; Hemolysin; Non-O157

\section{Introduction}

Strains of non-0157 STEC have been isolated from patients with hemorrhagic colitis (HC). Some of these isolates have been associated with the hemolytic uremic syndrome (HUS) in infected persons [1-4]. Four clonallyrelated groups of STEC have been identified and are designated EHEC 1, EHEC 2, STEC 1, and STEC $2[5,6]$. Members of EHEC groups 1 and 2 encode the locus of enterocyte effacement (LEE) and produce intimin, an adherence factor common to both EHEC groups $[6,7]$. The O157:H7 strains that cause most of the major outbreaks of STEC-related illness typically belong to the EHEC 1 group. STEC 1 and 2 members typically do not encode the gene for

\footnotetext{
* Corresponding author. Tel.: +1-301-295-3400; Fax: +1-301-2953773.

E-mail address: aobrien@usuhs.mil (A.D. O’Brien).
}

intimin nor do they carry the LEE pathogenicity island [6]. Serotype 091:H21 strain B2F1 [8] lacks the LEE locus, as determined by Southern blot with LEE-locus probes [9], and is categorized as an STEC 1 group member. B2F1 was originally isolated from a patient with HUS (personal communication, Dr M. Karmali). We hypothesized that B2F1, like other clinical isolates of intimin-negative STEC [10-12], has the capacity to adhere to epithelial cells by an intimin-independent mechanism. Therefore, we attempted to define factors important for the adherence of B2F1 to human intestinal epithelial cells. Although an intestinal cell adhesion for the intimin-negative 091:H21 STEC strain was not identified, three new findings were generated from this study. First, we found that the H-NS protein regulates, in a positive manner, the adherence of $\mathrm{B} 2 \mathrm{~F} 1$ to $\mathrm{T} 84$ human colonic epithelial cells, as well as the motility of B2F1. Second, we demonstrated that H-NS negatively regulates the plasmid-encoded hemolysin and chromosomally 
encoded alkaline phosphatase produced by B2F1. Third, a plasmid-cured strain of B2F1 was used to show that the large plasmid is not required for $\mathrm{B} 2 \mathrm{~F} 1$ to adhere to $\mathrm{T} 84$ cells.

\section{Results and discussion}

\subsection{Rationale for selection of bacterial strain and eukaryotic cells}

Strain B2F1, a human 091:H21 isolate that has two copies of the Stx2d-activatable $[8,13]$ adhered to T84 cells at consistently high levels (Fig. 1A). The laboratory E. coli control strain DH5 $\alpha$ adhered poorly to T84 cells (not shown). T84 cells were used as the model cell line for adherence for two reasons. First, T84 cells are not sensitive to killing by Stx because they lack the toxin binding receptor [14]. Second, under the appropriate in vitro conditions the T84 human colonic adenocarcinoma cell line grows in a polarized manner and resembles the native intestinal colonic crypt cell from which it was derived [15]. We found that B2F1 adhered with a similar phenotype (large irregularly shaped colonies) to both polarized and non-polarized T84 cells (not shown). Therefore, we elected to use non-polarized T84 cells for most of this study for ease of maintenance and growth but confirmed all adherence results with polarized T84 cells.

\subsection{Isolation of mini-Tn5phoA $\mathrm{Cm}^{r}$ adherence mutants}

B2F1 was mutagenized with a mini-Tn5phoACm ${ }^{\mathrm{r}}$ transposon to screen for mutants with insertions in potential adhesins. The mini-Tn $5 p h o A \mathrm{Cm}^{\mathrm{r}}$ used in this study was generated by replacing the kanamycin resistance gene in
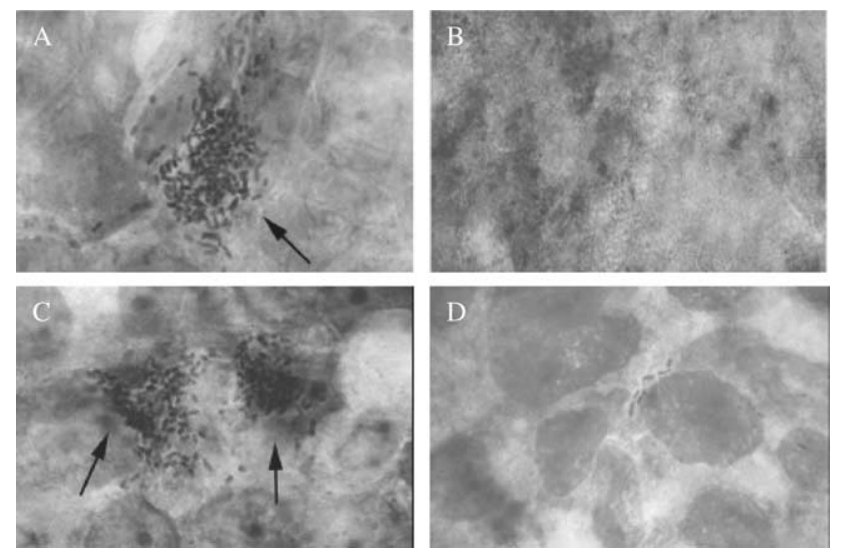

Fig. 1. Phase contrast microscopy shows the reduced capacity of strains with mutations in hns to adhere to T84 cells as compared to wild-type. The parental wild-type strain $\mathrm{B} 2 \mathrm{~F} 1$ is shown in panel A and its isogenic plasmid-cured derivative, S11, is shown in panel C; both strains exhibit a wild-type adherence phenotype on T84 cells. In contrast, hns mutants 34.7 (panel B) and S11358.19 (panel D) are deficient in adherence. Arrows indicate clusters of adherent bacteria.
mini-Tn5phoA [16] with a chloramphenicol resistance gene (not shown). Chloramphenicol was used as the selective marker in the mutagenesis rather than kanamycin because B2F1 mutates to kanamycin resistance at a high frequency. We isolated 22,555 chloramphenicol resistant transconjugates of B2F1. Approximately $1 \%$ of the chloramphenicol resistant transconjugates were blue when grown on LuriaBertani (LB) agar with the phosphatase substrate 5-bromo4-chloro-3-indolyl phosphate (XP). The blue mutants that contained putative active alkaline phosphatase fusions to exported proteins were screened for the capacity to bind to confluent T84 cells. Briefly, wild type and mutant strains were allowed to associate with T84 cells in plastic chamber slides for a total of $3 \mathrm{~h}$ at $37{ }^{\circ} \mathrm{C}$ in $5 \% \mathrm{CO}_{2}$. Samples were washed 10 times with fresh Dulbecco's PBS supplemented with $\mathrm{Ca}^{2+} / \mathrm{Mg}^{2+}$ fixed and stained with Leukostat (modified Wright's stain from Fisher Scientific, New Hampshire), and screened qualitatively by phase contrast microscopy (assay modified from) $[17,18]$. Quantitative analysis was done in a similar manner except trypsin was added to the 8-well chamber slides after the $3 \mathrm{~h}$ incubation period. The bacterial-eukaryotic cell suspension was then serially diluted and plated on LB agar to obtain viable colony counts. Each sample was done in triplicate. The geometric mean adherent $\mathrm{CFU}$ was calculated for each strain tested. Of the 253 mutants screened, two, 34.3 and 34.7 , had a reduced adherence phenotype (Fig. 1B shows 34.7). Quantitative analysis of a $3 \mathrm{~h}$ adherence assay on polarized T84 cells revealed that approximately $10^{5} \mathrm{CFU} / \mathrm{ml}$ of strains 34.3 or 34.7 were recovered from each well of the chamber slide as compared to $10^{7} \mathrm{CFU} / \mathrm{ml}$ of wild-type B2F1.

Southern hybridization analysis of HindIII-restricted genomic DNA from the mutants (34.7 and 34.3) with reduced adherence showed that each mutant appeared to contain a single insertion in an approximately $6 \mathrm{~kb}$ DNA fragment (data not shown). Furthermore, double-restriction enzyme Southern blot analysis of the two mutants revealed that the insertion was in the same DNA fragment (data not shown). Therefore, only 34.7 was analyzed further.

\subsection{Sequence analysis of the mini-Tn5phoACm ${ }^{r}$ disrupted gene of mutant 34.7}

The $6 \mathrm{~kb}$ HindIII DNA fragment that contained the mini$\mathrm{Tn} 5 p h o A \mathrm{Cm}^{\mathrm{r}}$ from mutant 34.7 was cloned by classical methods [19] into pBR322 and sequenced. Analysis of that sequence revealed that the transposon had inserted near the start of the B2F1 hns gene. However, the sequence analysis also showed that $h n s$ and $p h o A$ were not in the same reading frame, a finding that indicated that neither a functional $\mathrm{H}$ NS nor a functional alkaline phosphatase fusion protein could be produced in 34.7. Therefore, we concluded that $\mathrm{H}$ NS regulates the expression of the native alkaline phosphatase in $\mathrm{B} 2 \mathrm{~F} 1$, since 34.7 produced blue colonies on media with XP. Other investigators have reported similar findings when H-NS was inactivated [20]. 


\subsection{Phenotypic analysis and complementation of mutant 34.7 with native $H$-NS}

Inactivation of $\mathrm{H}-\mathrm{NS}$ affects the expression of several unlinked and unrelated genes encoded in $E$. coli and Salmonella typhimurium [21,22]. Therefore, several characteristics of 34.7 that are potentially relevant to STEC virulence were examined. Mutant 34.7 grew at rates similar to B2F1 and expressed Stx2d-activatable at wild-type levels (not shown), but unlike the parental B2F1 strain, mutant 34.7 was nonmotile (Table 1). However, the non-motile phenotype of 34.7 was most likely not responsible for the failure of 34.7 to adhere to T84 cells, since other mini$\mathrm{Tn} 5$ phoACm ${ }^{\mathrm{r}}$ non-motile mutants did adhere to T84 cells (not shown). Strain 34.7 also produced large zones of hemolysis on agar that contained 5\% washed sheep red blood cells (SRBCs) in contrast to the small turbid zones of hemolysis produced by wild-type B2F1, Table 1 . The hemolysin operon is located on the large $\sim 90 \mathrm{~kb}$ plasmid carried by the vast majority of EHEC and STEC clinical isolates [23]. However, hemolytic activity is generally not detectable in the cell-free filtrates of wild-type STEC [23], an observation that we confirmed with B2F1 (not shown). In contrast, hemolytic activity was detectable in culture supernatants of 34.7 and was quantifiable by a hemolytic tube assay [24], Table 1. Furthermore, the amount of hemolysin in bacterial culture supernatants and whole cell lysates of 34.7 was greater than that produced by the parent (Table 1), as determined by Western blot analysis with antibody raised against $\alpha$-hemolysin [24]. Thus, these Western blot data taken together with the hemolytic phenotype of 34.7 noted on SRBC agar and in tube assays indicate that hemolysin production is deregulated in 34.7. Similarly, H-NS in complex with Hha, a protein that belongs to a relatively new family of modulators, controls the expression of the thermoregulated $\alpha$-hemolysin operon encoded by uropathogenic Escherichia coli [25].
The adherence capacity of mutant 34.7 was restored to wild-type levels when hns was introduced into 34.7 on a moderate copy number plasmid while transformation with the vector alone failed to complement the adherence defect of 34.7 (data not shown). This finding confirmed that the hns mutation in 34.7 was responsible for the defect in adherence. Similarly, the wild-type hemolytic phenotype was restored in mutant 34.7 complemented with wild-type hns, as demonstrated by small turbid zones of hemolysis around the colonies on SRBC agar (not shown, see Table 1 for a summary of phenotypic data).

\subsection{Construction of a hns insertion mutation in a plasmid- cured derivative of $\mathrm{B} 2 \mathrm{~F} 1$ and assessment of the capacity of that mutant to adhere to T84 cells}

We next sought to separate the reduced adherence phenotype of 34.7 from the hyper-hemolytic phenotype exhibited in that mutant by constructing a hns mutation in a B2F1 derivative lacking hemolysin. First, a hemolysin negative derivative of B2F1 was generated by curing the large plasmid from a mutant of $\mathrm{B} 2 \mathrm{~F} 1$ that carried a miniTn 5 phoA $\mathrm{Cm}^{\mathrm{r}}$ insertion on the large plasmid. The mutant was cured by repeated passaging of the mutant in LB containing ampicillin/cycloserine. Of 11 chloramphenicol sensitive derivatives of the mutant, one, strain S11, was found not to hybridize to the probe for the large plasmid [26] and did not have a visible large plasmid present in plasmid preparations (not shown). As expected, S11 still adhered to T84 cells with a wild-type phenotype (Fig. 1C) and was not hemolytic on SRBC agar (Table 1). Second, an hns mutation was introduced into the non-hemolytic S11 by integration of a mobilizable suicide plasmid that contained a portion of the $h n s$ coding sequence into the wild-type hns in S11. (Note: repeated attempts to transfer the null mutation from 34.7 to S11 by allelic exchange or P1 transduction failed.)

Table 1

Genotypic and phenotypic characteristics of B2F1, S11 and their isogenic hns mutants

\begin{tabular}{|c|c|c|c|c|c|c|}
\hline \multirow[t]{2}{*}{ Strain } & \multirow[t]{2}{*}{ Relevant genotype } & \multicolumn{5}{|l|}{ Phenotype } \\
\hline & & Alkaline phosphatase $\mathrm{a}^{\mathrm{a}}$ & Adherence $^{\mathrm{b}}$ & Hemolysis (titer) $^{\mathrm{c}}$ & Hemolysin $^{\mathrm{d}}$ & Motility $^{\mathrm{e}}$ \\
\hline $\mathrm{B} 2 \mathrm{~F} 1$ & $\mathrm{Wt}$ & $-1+$ & + & $-/+(0)$ & - & +++ \\
\hline 34.7 & $\mathrm{~B} 2 \mathrm{~F} 1$ hns $::$ mini-Tn5phoACm ${ }^{\mathrm{r}}$ & ++ & - & $++(8)$ & + & - \\
\hline 34.7 (pHNS) & $\mathrm{B} 2 \mathrm{~F} 1$ hns $::$ mini-Tn $5 p h o A \mathrm{Cm}^{\mathrm{r}}$ (pHNS) & - & + & $-/+(\mathrm{ND})^{\mathrm{f}}$ & ND & + \\
\hline S11 & B2F1 (large plasmid cured) & $-1+$ & + & $-(\mathrm{ND})$ & - & ++ \\
\hline S11358.19 & S11 hns :: pMS358 & + & - & ND (ND) & ND & + \\
\hline S11358.19 (pHNS) & S11 hns :: pMS358 (pHNS) & - & + & ND (ND) & ND & + \\
\hline
\end{tabular}

a Alkaline phosphatase was determined as blue colony color after growth on LB plates with XP.

b Adherence was measured on T84 cells as described in the text.

c Hemolysis was detected as a clearing of red blood cells around colonies grown on tryptose blood agar with $10 \mathrm{mM} \mathrm{CaCl}{ }_{2}$ and $5 \% \mathrm{SRBC}$. The hemolytic titer was determined as the recipricol dilution where lysis of sheep erythrocytes was evident after $2 \mathrm{~h}$ at $37^{\circ} \mathrm{C}$.

d Hemolysin was detected by Western blot with antibody to $\alpha$ hemolysin [24].

e Motility was assayed after growth in semi-solid agar plates at $30{ }^{\circ} \mathrm{C}$ overnight.

${ }^{\mathrm{f}}$ ND-not determined. 
Successful insertional inactivation of a gene by this method has been previously reported [27].

The construction of the hns mutation in S11 is described briefly as follows. First, a 358 bp portion of hns from S11 was amplified by the polymerase chain reaction (PCR). Second, the truncated hns PCR product was ligated into a temperature-sensitive suicide plasmid, pSTAMP [28], to generate plasmid pMS358. Third, plasmid pMS358 was electroporated into $\mathrm{S} 11$ and transformants that were ampicillin resistant were recovered at $30{ }^{\circ} \mathrm{C}$. Fourth, stable colonies of S11 (pMS358) were incubated overnight at $44^{\circ} \mathrm{C}$ on agar containing ampicillin to select for colonies with pMS358 integrated into hns encoded on the chromosome of S11. Putative cointegrates were analyzed by PCR and Southern blot analysis to confirm that integration of the plasmid into hns had occurred (not shown). Insertion of the plasmid into wild-type hns generated two incomplete copies of hns only one of which retained an intact promoter region. The H-NS produced from the copy of hns with an intact promoter was predicted to lack six amino acid residues at its carboxy-terminal end.

The in vitro growth rate of the S11 hns mutant, S11358.19, was similar to that of wild-type S11 (not shown). However, as predicted, S11358.19 showed reduced adherence to T84 cells compared to S11 (Fig. 1D). Furthermore, a quantitative adherence assay demonstrated that $10^{5} \mathrm{CFU} / \mathrm{ml}$ of $\mathrm{S} 11358.19$ were recovered as compared to $10^{6} \mathrm{CFU} / \mathrm{ml}$ of its parental strain $\mathrm{S} 11$ and $\mathrm{B} 2 \mathrm{~F} 1$. (The reason for the lower overall adherence of the wild-type $\mathrm{B} 2 \mathrm{~F} 1$ in this set of assays as compared to the assays described above is unknown, however, the adherence of B2F1 and S11 was consistently 10-fold higher than that of the hns mutant of S11.) These results demonstrate that the absence of H-NS function, not the presence of increased STEC hemolysin, was responsible for the reduction in the adherence of mutant 34.7 to T84 cells. Mutant S11358.19 was also blue on XP agar and exhibited reduced motility, whereas the hns mutant of $\mathrm{B} 2 \mathrm{~F} 1$ was non-motile, Table 1. This result suggested that the activity of H-NS in mutant S11358.19 was not completely ablated. When S11358.19 was transformed with a low copy number plasmid that encoded full-length H-NS protein, the adherence and alkaline phosphatase phenotypes were restored to wildtype levels (not shown). However, full motility was not restored to S11358.19 (pHNS), see Table 1. One explanation for this finding is that the truncated H-NS polypeptide produced by the mutant S11358.19 interacted with wild-type H-NS supplied in trans, which, in turn, resulted in a decrease in H-NS activity. Such a dominant negative phenotype is plausible since H-NS is thought to act as an oligomer or homodimer [22,29].

In summary, hns mutations in $\mathrm{B} 2 \mathrm{~F} 1$ or its plasmid-cured derivative $\mathrm{S} 11$ reduced the capacity of those mutants to adhere to T84 cells and resulted in a reduction in motility and an elevation in alkaline phosphatase activity. In B2F1 the hns mutation also increased the plasmid-encoded hemolytic activity. Regulation of STEC-hemolysin expression in STEC or 0157:H7 has not been previously described. Furthermore, genes encoded by the large plasmid have not been reported to be controlled by chromosomal gene products in STEC. In the enteropathogenic E. coli (EPEC) regulation of attachment and effacement genes by Ler, which is homologous to H-NS of Salmonella, has been reported [30]. Bustamante and colleagues showed that Ler activates transcription of LEE genes by competing for binding with $\mathrm{H}-\mathrm{NS}$ and that in the absence of Ler H-NS represses the expression of LEE genes important in $\mathrm{AE}$ lesion formation [31]. For O157:H7 EHEC strains, hns has been suggested to be a repressor of the espA operon [32], the products of which are involved in early steps of adherence. Although Ler is also present in E. coli 0157:H7, intiminnegative STEC do not encode either the LEE pathogenicity island or the Ler gene. Furthermore, our report suggests that H-NS may play a somewhat different role in the regulation of B2F1 adherence. The eventual identification of gene(s) that encode STEC adhesins in LEE-negative stains will facilitate our understanding of the mechanism by which $\mathrm{H}$ NS regulates adherence.

\section{References}

[1] Bokete TN, Whittam TS, Wilson RA, Clausen CR, O'Callahan CM, Moseley SL, Fritsche TR, Tarr PI. Genetic and phenotypic analysis of Escherichia coli with enteropathogenic characteristics isolated from Seattle children. J Infect Dis 1997;175:1382-9.

[2] Bonnet H, Souweine B, Gauthier G, Rich C, Livrelli V, Sirot J, Joly B, Forestier C. Non-0157:H7 Stx2-producing Escherichia coli strains associated with sporadic cases of hemolytic-uremic syndrome in adults. J Clin Microbiol 1998;36:1777-80.

[3] Griffin PM. Escherichia coli 0157:H7 and other enterohemorrhagic Escherichia coli. In: Blaser MJ, Smith PD, Ravdin JI, Greenberg HB, Guerrant RL, editors. Infections of the gastrointestinal tract. NewYork NY: Raven Press Ltd.; 1995. p. 739-61.

[4] Willshaw GA, Scotland SM, Smith HR, Cheasty T, Thomas A, Rowe B. Hybridization of strains of Escherichia coli 0157 with probes derived from the eaeA gene of enteropathogenic E. coli and the eaeA homolog from a vero cytotoxin-producing strain of $E$. coli 0157 . J Clin Microbiol 1994;32:897-902.

[5] Schmidt H, Geitz C, Tarr PI, Frosch M, Karch H. Non-O157:H7 pathogenic Shiga toxin-producing Escherichia coli: phenotypic and genetic profiling of virulence traits and evidence for clonality. J Infect Dis 1999;179:115-23.

[6] Whittam TS. Evolution of Escherichia coli O157:H7 and other Shiga toxin-producing E. coli strains. In: Kaper JB, O'Brien AD, editors. Escherichia coli $\mathrm{O} 157: \mathrm{H} 7$ and other Shiga toxin-producing E. coli strains. Washington, DC: ASM Press; 1998. p. 195-209.

[7] McDaniel TK, Jarvis KG, Donnenberg MS, Kaper JB. A genetic locus of enterocyte effacement conserved among diverse enterobacterial pathogens. Proc Natl Acad Sci USA 1995;92:1664-8.

[8] Ito H, Terai A, Kurazono H, Takeda Y, Nishibuchi M. Cloning and nucleotide sequencing of Vero toxin 2 variant genes from Escherichia coli $091: \mathrm{H} 21$ isolated from a patient with the hemolytic uremic syndrome. Microb Pathog 1990;8:47-60.

[9] Scott M. Mutations in the histone-like nucleoid structuring regulatory gene (hns) decrease the adherence of Shiga toxin-producing Escherichia coli 091:H21 strain B2F1 to human colonic epithelial 
cells and increase the production of hemolysin. Ph.D. Dissertation. Uniformed Services University of the Health Sciences, Bethesda, MD. 1999; p. 66-69.

[10] Dytoc MT, Ismaili A, Philpott DJ, Soni R, Bruton JL, Sherman PM. Distinct binding properties of $e a e A$-negative verocytotoxin-producing Escherichia coli O157:H7 of serotype O113:H21. Infect Immun 1994; 62:3494-505.

[11] Paton AW, Srimanote P, Woodrow MC, Paton JC. Characterization of Saa, a novel autoagglutinating adhesin produced by locus of enterocyte effacement-negative Shiga-toxigenic Escherichia coli strains that are virulent for humans. Infect Immun 2001;69: 6999-7009.

[12] Srimanote P, Paton AW, Paton JC. Characterization of a novel type IV pilus locus encoded on the large plasmid of locus of enterocyte effacement-negative Shiga-toxigenic Escherichia coli strains that are virulent for humans. Infect Immun 2002;70:3094-100.

[13] Melton-Celsa AR, O'Brien AD. Activation of Shiga-like toxins by mouse and human intestinal mucus correlates with virulence of enterohemorrhagic Escherichia coli 091:H21 isolates in orally infected, streptomycin-treated mice. Infect Immun 1996;64:1569-76.

[14] Philpott DJ, Ackerley CA, Kiliaan AJ, Karmali MA, Perdue MH, Sherman PM. Translocation of verotoxin-1 across T84 monolayers: mechanism of bacterial toxin penetration of epithelium. Am J Physiol 1997;273:G1349-58.

[15] Dharmsathaphorn K, Madara JL. Established intestinal cell lines as model systems for electrolyte transport studies. Methods Enzymol 1990;192:354-89.

[16] De Lorenzo V, Herrero M, Jakubzik U, Timmis KN. Mini-Tn5 transposon derivatives for insertion mutagenesis, promoter probing, and chromosomal insertion of cloned DNA in Gram-negative eubacteria. J Bacteriol 1990;172:6568-72.

[17] Cravioto A, Gross RJ, Scotland SM, Rowe B. An adhesive factor found in strains of $E$. coli belonging to the traditional infantile enteropathogenic serotypes. Curr Microbiol 1979;3:95-9.

[18] Winsor Jr. DK, Ashkenazi S, Chiovetti R, Cleary TG. Adherence of enterohemorrhagic Escherichia coli strains to a human colonic epithelial cell line (T84). Infect Immun 1992;60:1613-7.

[19] Maniatis T, Fritsch EF, Sambrook J. Molecular cloning: a laboratory manual. Cold Spring Harbor, NY: Cold Spring Harbor Laboratory; 1989.

[20] Woolwine-Ciacci F, Blomfield IC, Richardson SH, Mizel SB. Salmonella flagellin induces tumor necrosis factor alpha in a human promonocytic cell line. Infect Immun 1998;66:1127-34.
[21] Atlung T, Ingmer H. H-NS: a modulator of environmentally regulated gene expression. Mol Microbiol 1997;24:7-17.

[22] Dorman CJ, Hinton JC, Free A. Domain organization and oligomerization among H-NS-like nucleoid-associated proteins in bacteria. Trends Microbiol 1999;7:124-8.

[23] Schmidt H, Beutin L, Karch H. Molecular analysis of the plasmidencoded hemolysin of Escherichia coli 0157:H7 strain EDL 933. Infect Immun 1995;63:1055-61.

[24] Bauer M, Welch RA. Characterization of an RTX toxin from enterohemorrhagic Escherichia coli O157:H7. Infect Immun 1996;64: $167-75$.

[25] Madrid C, Neito JM, Paytubi S, Falconi M, Gualerzi CO, Juarez A. Temperature- and H-NS-dependent regulation of a plasmid-encoded virulence operon expressing Escherichia coli hemolysin. J Bacteriol 2002;184:5058-66.

[26] Levine MM, Xu JG, Kaper JB, Lior H, Prado V, Tall B, Nataro J, Karch $\mathrm{H}$, Wachsmuth K. A DNA probe to identify enterohemorrhagic Escherichia coli of $0157: \mathrm{H} 7$ and other serotypes that cause hemorrhagic colitis and hemolytic uremic syndrome. J Infect Dis 1987; 156:157-82.

[27] Taylor RK, Miller VL, Furlong DB, Mekalanos JJ. Use of phoA gene fusions to identify a pilus colonization factor coordinately regulated with cholera toxin. Proc Natl Acad Sci USA 1987;84:2833-7.

[28] Teel L, Melton-Celsa AR, Schmitt CK, O'Brien AD. One of two copies of the gene for the activatable Shiga toxin type $2 \mathrm{~d}$ (Stx2d) in Escherichia coli $091: \mathrm{H} 21$ strain $\mathrm{B} 2 \mathrm{~F} 1$ is associated with an inducible bacteriophage. Infect Immun 2002;70:4282-91.

[29] Tanaka K, Muramatsu S, Yamada H, Mizuno T. Systematic characterization of curved DNA segments randomly cloned from Escherichia coli and their functional significance. Mol Gen Genet 1991;226:367-76.

[30] Elliott SJ, Sperandio V, Girón JA, Shin S, Mellies JL, Wainwright L, Hutcheson SW, McDaniel TK, Kaper JB. The locus of enterocyte effacement (LEE)-encoded regulator controls expression of both LEE- and non-LEE-encoded virulence factors in enteropathogenic and enterohemorrhagic Escherichia coli. Infect Immun 2000;68: 6115-26.

[31] Bustamante VH, Santana FJ, Calva E, Puente JL. Transcriptional regulation of type III secretion genes in enteropathogenic Escherichia coli: Ler antagonizes H-NS-dependent repression. Mol Micro 2001; 39:664-78.

[32] Beltrametti F, Kresse AU, Guzman CA. Transcriptional regulation of the esp genes of enterohemorrhagic Escherichia coli. J Bacteriol 1999;181:3409-18. 